\title{
Love and Art Creation: Rodin and Camille Claudel
}

\author{
Michelle Morin-Bompart \\ Department of Psychiatry, CHU Broussais Hotel Dieu, University of Paris VI, Paris, France
}

Email address:

michelle.morin75@orange.fr

\section{To cite this article:}

Michelle Morin-Bompart. Love and Art Creation: Rodin and Camille Claudel. Psychology and Behavioral Sciences. Vol. 7, No. 3, 2018, pp. 56-61. doi: 10.11648/j.pbs.20180703.13

Received: August 15, 2018; Accepted: September 10, 2018; Published: October 9, 2018

\begin{abstract}
Rodin and Camille Claudel's loves were passionate and tumultuous, a short blaze between 1885 and 1892, only seven years of their life! Their works reveal their loving passion. Each one has his own talent. Rodin and Camille Claudel have influenced each other and their works answer to one another. Rodin finds in Camille an elder sister who understands him, with whom he can share his passion for sculpture. Both of them have been fascinated by modeling clay. Camille will find in Rodin a father who encouraged her talent for sculpture and a beloved brother with whom she had great complicity. The Kiss of Rodin suggests the beginning of their love and Camille's Sakountala is the answer and proof of it. Camille's Middle Age and Rodin's Fugit Amor reveal the end. Love inspires creators. Freud says that sexual drives are sublimated in creative surges. Consciously or not, the creators express their love passion and sexual desires in their creations. André Green says that you can't split the creator's life from his creations. The creator's unconscious can reveal a lot from their love affairs and secrets. This is the case for Camille and Rodin. Of course we don't have the real proof that they had two children together, except for Jessie's testimony and the photo of Camille sculpting Sakountala. We can read in creators' works like in dreams and I am convinced that creations are also a royal path, like dreams, leading to the unconscious of their creators.
\end{abstract}

Keywords: Love, Creation, Art, Sculpture, Unconscious

\section{Introduction}

Rodin and Camille Claudel's loves were passionate and tumultuous, a short blaze between 1885 and 1892, only seven years of their life!!! Their works reveal their loving passion. Each one has his own talent. Rodin and Camille Claudel have influenced each other and their works answer to one another.

The love feeling has its roots in the infant's attachment to his first object $[7,8]$. The new born baby is attached to his mother or her substitute in a merging way. This loving tenderness is linked also to the pleasant sensations he feels during the maternal care of his body. This tenderness is not sexualized but source of pleasure for the child. At the age of three or four, the child is in love with the parent of the opposite sex and will experience again at puberty this œdipian love feeling. The incestuous desire is struck by prohibition, the incest prohibition, resolved by the renouncement of the incestuous object and investment of another object.

Love is an affect, a feeling, an experience of body and mind. The heart is a body organ and feelings accelerates heart beats. The tender current is normally linked to the sexual current. In the act of love, the loving feeling conducts to the satisfaction of the sexual tension where phantasies have a large role, with an identification to the partners of the primal scene. During a long time the act of love has been considered from the point of view of procreation in order to provide descendants to the family and species, with a phantasy of immortality. A social and religious contract controlled love and sexual life. In our days the search of pleasure and orgasm have more importance than the love affect, since birth control. During a long time, love feelings have been repressed by financial interests, alliance between families, political alliances for the kings and emperors. This still exist in Africa, in some Muslim countries, in India, but the liberty of choice and the individual happiness wins in our occidental civilization.

You need to be loved and well loved by a loving mother (or nurse) to be able to love somebody else. Love arises from the encounter between a man and a woman: it is an illusion [7] which comes from our odipian objects and precocious relationship with the maternal object. The encounter between those two exceptional personalities, Rodin and Camille, will 
lend to their love passion.

\section{Method}

We shall study Rodin and Camille's life before their encounter which will reveal their early loves, then when they meet for the first time and their passionate love during seven years.

\subsection{Rodin and Camille's Life Before Their Encounter}

\subsubsection{Rodin's Life}

August Rodin's grandparents were weavers, on both side. His father was a police officer. Married first to Gabrielle, he took for second spouse Mary, Rodin's mother. Three cousins on his mother's side were engraver, printer and commercial designer. Mary gives birth to Maria the elder sister and August comes to light two years later in 1840. [12]

Rodin says he had a difficult childhood and adolescence. His parents were catholic and August will go in a catholic school where he learns very slowly to read and write. He draws and copy engravings. He likes to model with his hands bread or clay balls and let them drag all around (good example of anal symbolism). We find this same necessity to touch like Camille Claudel for another reason...Maria stimulates her younger brother, she is very proud of him, worry for his future and encourages him. August acquired culture with his paternal uncle: he likes the ancient French poets and authors and consider to become an orator. He has a passion for gothic architecture.

When he is fourteen years old, he discovers engravings from Michel-Ange: "Consumed by the desire of modeling sculptures, I had found my bent" did he say. This is an heroic identification [1]. His father agrees and he follows drawing courses at the Little School (the Big one is the Beaux Arts). They won't be any living models until 1858, four years later. But Rodin will be chiefly interested by nude.

Rodin is mostly a self-taught man. He tried the contest to enter the Beaux Arts but was not accepted because his drawings were very different from the others. His father attempted to dissuade him of becoming a sculptor but Rodin decided to succeed by himself without a teacher. He needs to earn his life and works during the day as a mason apprentice and sculpt at night: fourteen hours of work every day: "I always fiercely loved work... an ardent nervous overexcitement drove me to work without rest." He takes free drawing lessons at the Manufacture des Gobelins from five to seven pm!!! He paints a portrait of his father, severe, and another one of his mother. He says about her: "You are the prettiest of all women, mother. I see your soul." We can imagine that Rodin had a very close odipian relationship with his mother (and his sister).

In 1862, Maria is in love with a friend of Rodin, a sculptor, but he marries somebody else. She enters a convent as a novice and comes out a few months later, sick and dies in her family from peritonitis. The death of this tenderly beloved sister plunges August in despair. Rodin, twenty-two years old, enters the Congregation of the Saint Sacrement, becomes steady again and realizes that an ecclesiastic life is not his goal.

He installs himself in an atelier in Paris but can't afford to pay for models. He takes the man in charge of his house keeping: the sculpture The Man with a broken nose froze during the winter... In 1864 (the year of Camille Claudel's birth) at the age of twenty-four, he meets Rose Beuret, eighteen years old, a sewer, who accepts to be his model. They fall in love of each other and she settles down in his home and awake his sensuality. They will have a son. Rose has been the model and muse of Rodin : Young Girl with a flowery hat 1865, The Source or The Maternity1867, Mignon 1869, The Young Alsatian 1871.

\subsubsection{Camille Claudel's Life}

Camille, since her childhood, draws and feels the need to knead clay and create objects. Is it a talent or simply an imperious necessity to draw, touch, knead with her fingers mother-earth and bring to life objects? Their mother, will say Paul, is a mother who doesn't touch, kiss, fondle, a cold and distant mother [3] .Also touching, kneading clay, seems to be a way to satisfy her desire to be touched, kissed, fondled by a mother grieving the death of an eldest son at the age of two weeks, a year before Camille's birth. Camille is a replacement child $[14,15]$. Her mother expected a boy, an eldest boy and rejected her daughter. The talent and artistic passion of Camille will be encouraged by her father.[2,5,13]

Where did she learn to knead clay? Her maternal grandfather, a doctor, owned tile-works and an oven to cook the tiles. Camille is six years old when her family moves in Villeneuve sur Fère, where lives her grandfather [9]. Who learned to her where to find clay, how to model it and cook it in the oven: her grandfather, servants, workers in the tileworks? François Claudel, Paul's grandson, says she cooked her creations in her mother's oven!!! A burning maternal uterus...

Camille knows where to find clay and modeling became a passion she imposed around her in a tyrannical way. She engages Paul, Louise, the servants to go and fetch clay, prepare plaster and pose as a model. She transforms the attic in an atelier for her clay, wood and stone sculptures.

In the catholic school in Epernay, the drawing teacher showed with proud, portraits and drawings of Camille, who has a precocious talent for drawing and modeling.

When the family moves to Nogent sur Seine, her father go and meet a famous sculptor, Alfred Boucher, who came to visit Camille's atelier and accepted to give lessons to this very gifted young girl of thirteen years old. She already had realized David et Goliath (a little one who wins against a big one), Oedipe et Antigone (an incestuous father with his daughter), Napoleon, Bismark (two great personalities) ...

It was a great chance for Camille and Paul that their father engaged a tutor, Mr Colin, who will encourage the pleasure of reading and the inclination to be a writer for Paul. Mr Colin and Alfred Boucher gave the council to move to Paris and the father chose the best for his children.

In 1881 when Mrs Claudel settles down in Paris, Camille 
seventeen years old, enters the Colarossi Academy, where men and women are treated as equal, and Paul thirteen years old is accepted at Louis le Grand. Their father has his job in Rambouillet and will join the family each week end.

At seventeen years old, Camille realize two wonderful sculptures: the Old Helen immortalizing her nurse Victoire, and Paul's bust at thirteen as a roman emperor, her beloved brother. They are the accomplishment of her precocious talent for drawing and modeling and the dawn of her sculptor's destiny.

\subsection{Camille, Student, Collaborator and Muse of Rodin}

After a year at the Colarossi Academy, Camille chose to share an atelier with two English girls studying sculpture and friends met at the Academy, and asked Alfred Boucher to supervise their work once a week. In 1882, he leaves going to Italy and ask Rodin to replace him. [2, 5, 13]

1882 is the date of the encounter of Rodin and Camille in her atelier rue Notre Dame Des Champs. Rodin is forty-two years old and Camille eighteen. He is already a well-known sculptor, Camille is a gifted student who completes Mrs B's bust under his instructions.

Rodin noticed very rapidly Camille's exceptional talent. He was able to have exchanges about sculpture with her. Both of them have a very similar and intuitive approach. Camille reminds him his dear elder sister Maria, very close to him and encouraging, who died at the age of twenty-four in 1862.

Camille's face inspires Rodin: Camille's mask (1884), Dawn (1885), The Thought (1885), Camille with a phrygian cap (1886). Rodin in 1885 needs assistants for the Bourgeois of Calais and invites Camille and Jessie to rejoin him in his atelier at the Mable Deposit rue de l'Université. The presence of Jessie is reassuring for Camille's parents. Camille is very clever at sculpting marble and she will become a practitioner of Rodin who signs their works according to the tradition.

Rodin finds in Camille an elder sister who understands him, with whom he can share his passion for sculpture. Both of them have been fascinated by modeling clay. Their way of modeling is very similar. When Camille arrived in Paris, the director of the Beaux-Arts asked Camille if she had taken lessons with Rodin: well, she had not !!! Camille will find in Rodin a father who encouraged her talent for sculpture and a beloved brother with whom she had great complicity.

Rodin is passionately in love with Camille. She is a beautiful and sensual woman, inspiring Rodin's sculpture and answering to his passionate surges. He descends from a modest family and she comes from a catholic and middleclass background, where the tradition of marriage is very important. Rodin has lived with his mistress Rose Beuret for more than twenty years. They had a son together but he didn't acknowledge him, only a few months before his death...He doesn't want to be a spouse, neither a father.

Camille is very jealous of Rose Beuret but Rodin doesn't want to give her up. She takes care of the housework and of his sculptures, enveloping them in a wet cloth (as a mother...). Camille is very jealous also of the Abruzzesi sisters his models and in the same time his mistresses. They posed for very erotic works The Crouching woman which reminds us of Courbet's World Origin... Rodin has become libertine, licencious. He doesn't want to be tied up to a woman and loose his independence. Rose's puts on the role of the mother and Camille the role of the sister, and he wants to keep both of them, not ready to give up Rose and the temptations provided by his models. A naked woman with a beautiful body, posing for him must be a great temptation and arouse the masculine desire...

\subsection{Rodin and Camille's Passionate Loves (1885-1892)}

For the biographers, the beginning of Rodin's love for Camille is not easy to date. For me The Kiss of Rodin and Camille's Sakountala are the proof of it. The Kiss represents the couple of Paolo and Francesca of Dante's Comedy conceived by Rodin for his Hell's Door, which became an autonomous sculpture The Kiss, showed in an exhibit in June 1886 , a couple of great sensuality... like what he was may be experiencing with Camille!

Camille starts Sakountala [4], this very sensual couple who seems to answer to The Kiss of Rodin, when she meets again Rodin in October 1886, after a long stay of four months in England. The theme of Sakountala seems to be chosen consciously or unconsciously by Camille with what she may have experienced during those four months. She is very close to her inconscious: the theme of her sculpture The Middle Age [4] will prove it too...

She chose the story of an Indian prince who falls in love with a Brahman's daughter Sakountala. The prince gives her a wedding ring and forgets about it. Sakountala hides in the forest to give birth to their child. The lost ring is fished out a lake and the lovers can meet again. This is an Indian drama of the fifth century and Camille may have seen or heard about the ballet in Paris. Camille chose for her sculpture the moment when the lovers meet again! (when Rodin and her meet again in October 1886).

The photo of Camille sculpting Sakountala

The date of the photo is 1887 , the year after her stay in England and renewing with Rodin. Examining this photo I was surprised to notice that under the overalls, without a belt Camille's belly seemed to be prominent and Sakountala's belly also... Camille pregnant in 1887? And Sakountala also, faithfully to the legend... Another photo dated 1886 shows Camille and Jessie Lipscomb in Camille's atelier rue Notre Dame des Champs (may be when the fiancé of Jessie took this picture in March 1886). Camille's waist is thin with a belt around it. It is astonishing that nobody noticed the pregnancy of Camille, or denied it.

This is a quotation from Pascal: "We believe what we see, but we see what we look, and we look only what we want".

The contract signed by Rodin (October 12th 1886)

This contract is surprising: it was signed by Rodin when they met again after four months of separation, after Camille stayed four months in England (end of May to the middle of September). Rodin tried to see Camille in London and in Jessie's family but Camille refused to meet him. Why? 
May be we can find an explanation in that strange contract where Rodin engages himself to take exclusively Camille as a student, to plan a trip of six months in Italy after the exhibit in May 1887. Then Camille will be his wife and Carjat will take a picture of Camille. Carjat did take a wonderful picture of Camille dated 1886 (October, November, December?), a radiant Camille, with a thin waist, an elegant striped dress and a hat with feathers.

This is a private contract of exclusivity and marriage!!! Camille was brought up in a middle class family and when they were no birth control. This contract may be an insurance against the risk of being pregnant and of giving birth to a child without being married. May be it happened in 1886 ?

Jessie Lipscomb's testimony [12]

Jessie became a very good friend and confidant of Camille after they enter Rodin's atelier in 1885. Frederic Grunsfeld, Rodin's biographer, dedicates a whole chapter to Camille Claudel, and reveals Jessie's testimony found after her death (letters and documents of a private collection in London) which stayed a long time hidden: "Camille had two illegitimate children from Rodin. He paid for their education but did not want to recognize these two sons, just like for August Beuret, the son he had with Rose Beuret."

Rodin, like Jean-Jacques Rousseau, didn't want to assume marriage neither paternity. Camille would have been pregnant to the term twice but where and when did she give birth? A photo of Camille sculpting Sakountala (1887), suggests a delivery in 1887 . The choice of the theme of Sakountala let us think that she experienced this story with Rodin and gave birth to a child in 1886 , may be during the four months she spent in England far from her family... The contract signed by Rodin seems to go the same way.

Camille, Rodin's lover

The beginning of their love affair can't be before 1885 . After she enters Rodin's atelier, her brother Paul [3]feels abandoned by Camille who works from seven in the morning to seven in the evening and comes back home exhausted. Rodin rejoins his twenty years' mistress Rose Beuret. Did Camille pose naked for him? He seems to have been inspired by her slender body and long hair for his so sensual Danaid (1885). A letter from Rodin with no date, testify of his passionate love for Camille: "Why didn't you wait for me at the atelier. Let me see you every day... I kiss your hand, my friend, who gives me such high and ardent pleasures. Oh, divine beauty".

Camille's stay in England (May-September 1886)

This long stay in England puzzled me. Did she go there to hide the end of her pregnancy with the complicity of Jessie and her family? Camille and Jessie arrived at the end of May. Camille refused to see Rodin in London on May 29th but accepted in Jessie's family, on June 4th, staying distant. Rodin asked Jessie's mediation but after Camille's refusal went back to France. What happened? Did Rodin promise marriage and didn't keep his promise like the prince? Was Camille angry at him because he did not marry her and recognize the child? Camille was present for Jessie's engagement on June 13th. Was she at the end of her pregnancy? We don't have any photo. In July, we don't know where stayed Camille! Letters written to Jessie were destroyed and also Jessie's letters to Camille. Did they mention Camille's delivery? A photo in August1886 at her friend Amy Singer's home shows Camille with a thin waist. She sent the picture to her family. On the 12th of August, her brother Paul and the Lipscomb family rejoin her in Florence Jean's family at the island of Wight.0

Back in Paris in September 1886, Camille seems to experience the "blues" of England. It could be the blues of delivery...In a letter to Florence [6] who becomes a great friend, she writes: "I feel like if my heart was broken" "During the last diner in Shanklin I cried and could not eat" "I cried a lot during my travel back". Camille is leaving her friends, England where she spent her holidays but may be also the child born in secret in this country...

Second pregnancy and delivery: July 1887 ?

The year 1887 will be difficult for Camille. In a letter to Florence, she entrust to her that she is often physically and mentally exhausted: is it because of a second pregnancy which seems evident on the photo of Camille sculpting Sakountala? They will be no trip to Italy, neither marriage. Camille stayed in Paris in July which is not her habit: was-it for the delivery? She met her father in Compiègne on the 31 st of July where she planned to finish her vacation. Then she accepted an invitation of Florence in September but cancelled and went with Rodin to the castle of the Islette in Touraine. She was back in Paris on the 16th of October and left the family apartment in 1888 to rent her own apartment, paid by Rodin. After her stay in Touraine, Paul [3] discovered the truth (about her relationship with Rodin... and abortions or births?) and wrote in 1888 Fragment of a drama, the story of a sinner, who gave away her body... We can understand how Camille felt guilty...Paul was a convincing catholic! He destroyed the manuscript to spare his parents... Was it the drama of his sister Camille?

Camille will meet Rodin at the Clos Païen, their new atelier, where George Sand and Musset protected their love affair. We can imagine that Camille expected from Rodin an exclusive relationship but he will not give up Rose Beuret and they will be terrible scenes of jealousy between the two women, sometime fights!!! Rodin and Camille will be invited by the high Parisian society with other artists and Rodin will help her to obtain commands for her sculptures. May be was he a little jealous of Camille's success with Sakountala? Listen to the critics:

"The most extraordinary new work at the exhibit is Sakountala, a chaste and passionate group from a young girl..."

"It is prodigious that a so young woman has been able to conceive and realize with such a success a so important group... such delicacies in her creation, testified by the young man's hand, this trembling hand which hesitates to embrace Sakountala's body and the exquisite unconscious abandoning movement of the beloved woman (Léon Gauchez with the pen name of Paul Leroi).

Listen also to what Paul [3] wrote in 1951: 
"The man is kneeling, he is only desire, raising his face, he aspires to, he embraces, doesn't dare to grab, this marvelous being, this sacred flesh which is due to him from an upper level. She gives up, blind, mute, heavy, she gives up to love's weight, one of her arms hangs, detached like a branch with a fruit, the other one covers the breast and protects the heart, supreme sanctuary of her virginity."

Those gorgeous and poetic words are from an œdipian brother in love with his sister, talking of sacred flesh and virginity, incest prohibition.

The critics and the brother reveal their phantasies....very close to Camille's phantasies...

Camille's Middle Age signs the end of their love

Camille, may be, had two abortions (one sure) between 1890 and 1892. Abortion, for her brother and mother, and catholics, was killing a life. May be she preferred abortion instead of giving life to two babies she had to abandoned but felt very guilty about it.

\section{Result}

Camille is very close to her Unconscious. Middle Age like Sakountala refers to the drama between Camille and Rodin. Paul's intuition was not mistaken when he recognized his sister in The Implorant, the young girl imploring her lover, the middle age man. Rodin was furious to see his private life spread out... but he did the same with The Kiss and Fugit Amor!!! The critics saw in this allegory, Rodin pulled by his old mistress Rose Beuret, and abandoning his young mistress Camille. After the exhibit of Sakountala, Rodin never helped again Camille, financially.

The unconscious of the critics worked fine, the unconscious of Paul and Camille too, and the unconscious of Rodin also...Creations from an artist reveals their unconscious and secrets in their lives, for example Camille's Sakountala and Middle Age and Rodin's Kiss and Fugit Amor!!! Freud [10] noticed the anger of Moses in Michelangelo's sculpture linked to the pope Julius II...

\section{Discussion}

Love inspires creators. We have the example of Rodin and Camille in sculpture but also Romeo and Juliet of Shakespeare in literature (and Jansen's Gradiva by Freud) and the opera Tristan and Isolde of Wagner in music...

Freud says that sexual drives are sublimated in creative surges. Consciously or not, the creators express their love passion and sexual desires in their creations. Rodin and Camille shared both love passion and passion for sculpture. Artists are very close to their unconscious, especially Camille who experienced a psychotic paranoiac delusion for the last forty years of her life.

André Green says that you can't split the creator's life from his creations: he is right. The creator's unconscious can reveal a lot from their love affairs and secrets. This is the case for Camille and Rodin. Of course we don't have the real proof that they had two children together, except for Jessie's testimony and the photo of Camille sculpting Sakountala. It would be interesting to go to London and check Jessie's testimony, talk to the descendants of the Lipscomb family and seek for photos of Camille at Jessie's engagement. But I believe in the interpretation of artists' creations. When they are dead, we don't have their associations and interpretations but we can do the work for them, associating the photo of Camille sculpting Sakountala, the story of Sakountala and the possible story of Rodin and Camille...

\section{Conclusion}

We can read in the creator's works like in dreams and I am convinced that creations are also a royal path, like dreams, leading to the unconscious of their creator's with the same defense's mechanisms: displacement, condensation, figurability, dramatization.

Rodin and Camille's brief and intense love inspired those two genial creators and some wonderful works. Rodin didn't accept to quite Rose Beuret and marry Camille. He wanted to keep them both and was very unhappy when he lost Camille but we can understand Camille's point of view. Camille Claudel accomplished an out of common sculptor's destiny, linked first to Rodin, then alone, acquiring recognition at a time where it was very difficult for a woman, succeeding in an art which requires considerable physical strength and very expensive materials. She accomplished herself with talent in a man's job and spent the life of an emancipated woman, not in accordance with the middleclass moral and her mother's ethics. Rodin was charmed by this gifted student able to rival with him, and also a beautiful woman and passionate lover. There was a turn in her destiny in 1886 and 1887: she could have been a wife and a mother... Rodin had the age of her father: she wished to be his wife. Their great love led to great creations but not to a couple and family life in which Camille could have bloom avoiding the rupture and her loneliness and psychotic breakdown, and confinement. Her character wasn't may be easy and this must have counted in Rodin's decision. She chose to separate from Rodin to be distinguished from him (and from the dead eldest brother she replaced) and to be famous (the idealized eldest boy of her mother and father) and also trying to escape pregnancies and abortions out of marriage in times there were no birth control, a painful choice who lent her to ruin.

\section{References}

[1] ANZIEU Didier, The Work's Body, Gallimard, 1988.

[2] AYRAL-CLAUSE Odile, Camille Claudel, her life, Hazan Editions, 2008.

[3] BONA Dominique, Camille and Paul, Grasset Editions, 2006.

[4] BOUTE Gérard, Camille Claudel, the mirror and the night, the Amateur's editions, 2008.

[5] CASSAR Jacques, dossier Camille Claudel, library Séguier/ Archimbaud, 1988. 
[6] CLAUDEL Camille, Correspondence, Gallimard, 2003.

[7] DAVID Christian, The amorous state, Psychoanalytic Essays, Poche, Payot, 2001.

[8] FAIN Michel \& Denise BRUNSWEIG, Eros and Anteros, Poche, Payot, 2001.

[9] FAYARD Jeanne, Camille Claudel, birth of a vocation, Riveneuve editions, 2013.

[10] FREUD Sigmund, Moses and the Monotheism, Poche, Payot, 1939.

[11] GREEN André, the Unlinking, Psychanalysis anthropology and literature, Pluriel, 1998.
[12] GRUNFELD Frédéric, Rodin, library Fayard, 1988.

[13] MATTIUSI Véronique \& ROSAMBERT-TISSIER Mireille, Camille Claudel, a rebellious' itinerary, the Blue Rider's editions, 2014.

[14] SCHAUDER Silke, Procreation or creation? The jerky trajectory of Camille Claudel, Proceedings of the symposium of Cerizy, l'Harmattan, 2006.

[15] SCHAUDER Silke, Camille Claudel, From the life to the work, crossed looks, Proceedings of the symposium of Cerizyla-Salle, l'Harmattan, 2006. 